\title{
PERILAKU STRATEGI COPING PELAKU TAMBAK UDANG DALAM MERESPONS KEBIJAKAN PENATAAN PEMANFAATAN TANAH KESULTANAN
}

Kuncoro Cahyo Aji ${ }^{1}$, Muhadjir Darwin², Kwartarini Wahyu Yuniarti ${ }^{3}$, dan Nurhasan Ismail ${ }^{4}$

${ }^{1}$ Program Studi Kebijakan, Sekolah Pascasarjana, Universitas Gadjah Mada, Yogyakarta, ${ }^{2}$ Fakultas IImu Sosial dan IImu Politik, Universitas Gadjah Mada, Yogyakarta, ${ }^{3}$ Fakultas Psikologi, Universitas Gadjah Mada, Yogyakarta, ${ }^{4}$ Fakultas Hukum, Universitas Gadjah Mada, Yogyakarta

Korespondensi: Kuncoro Cahyo Aji (e-mail: kun_wi@yahoo.com)

\begin{abstract}
Abstrak
Kebijakan penataan pemanfaatan tanah kesultanan untuk tambak udang di Kabupaten Bantul Daerah Istimewa Yogyakarta telah menimbulkan bentuk strategi coping sebagai respons masyarakat yang berbeda-beda. Penelitian ini merupakan penelitian eksplorasi mengenai strategi coping petambak udang yang berbeda-beda dalam merespons kebijakan penataan tanah kasultanan. Hasil penelitian ini diketahui bahwa 1) terdapat bentuk strategi coping yang dilakukan para petambak udang dalam merespons kebijakan penataan pemanfaatan tanah kesultanan untuk tambak udang serta 2) adanya pengaruh emosi, kognisi, dan emosi dengan strategi coping para pelaku tambak udang. Strategi coping para petambak udang dalam merespons kebijakan tambak udang adalah mengkritisi keputusan pemerintah $(0,914)$, adanya sikap menerima $(0,894)$, penerimaan dengan terpaksa $(0,849)$, dan evaluasi diri $(0,561)$. Strategi coping tersebut dipengaruhi oleh persepsi negatif $(0,864)$, perbedaan pendapat $(0,851)$, kebingungan $(0,822)$, ekspektasi $(0,816)$, dan percaya diri $(0,657)$.
\end{abstract}

Kata kunci: strategi coping, kognisi, emosi

\section{BEHAVIOR OF COPING STRATEGY OF SHRIMP FISHERS IN RESPONDING TO THE POLICY OF LAND USE UTILIZATION OF THE SULTANATE}

\begin{abstract}
The policy of arranging the utilization of cultivated land for shrimp ponds in Bantul District of Yogyakarta Special Region has resulted in the form of coping strategies as different community responses. This research is an exploratory research on shrimp farmers coping strategies that vary in response to the policy of the landscape of the Sultanate. The results of this study are as follows. 1) There are forms of coping strategy conducted by shrimp farmers in responding to the policy of arranging the utilization of the land of sultanate for shrimp ponds; 2) There are influences of emotion, cognition and emotion with the coping strategy of shrimp farmers. The coping strategy of shrimp farmers in responding to shrimp farming policy is to criticize the government's decision (0.914), to accept the decision (0.894), to accept by forced (0.849), and to have self-evaluation (0.561). The coping strategy is influenced by negative perceptions $(0.864)$, disagreements (0.851), confusion (0.822), expectations $(0.816)$, and confidence $(0.657)$.
\end{abstract}

Keywords: coping strategy, cognition, emotion 


\section{PERILAKU STRATEGI COPING PELAKU TAMBAK UDANG DALAM MERESPONS KEBIJAKAN PENATAAN PEMANFAATAN TANAH KESULTANAN}

\section{Pendahuluan}

Secara umum, permasalahan yang berkaitan dengan pemanfaatan tanah banyak dijumpai pada kasus-kasus kontestasi pemanfaatannya. Persoalan pertanahan sering diawali dengan pemanfaatan yang tidak sesuai dengan peraturan perundangundangan, baik kepemilikan izin maupun kesesuaian tata ruangnya. Kontestasi tanah sering dimaknai sebagai perebutan ruang antara berbagai pihak yang berkepentingan sesuai dinamika wilayah dan keanekaragaman kebutuhan.

Konflik tersebut, di antaranya, terjadi di tanah sepanjang pantai selatan Daerah Istimewa Yogyakarta yang sebagian besar merupakan tanah milik Kesultanan Yogyakarta atau dalam bahasa Belanda disebut sebagai Sultanat Grond. Tanah di sepanjang Pantai Pandansimo sampai Depok, misalnya, telah lama dimanfaatkan masyarakat sekitar untuk tambak udang, pariwisata, pertanian cabai, bawang merah, dan buah naga. Berdasarkan pendataan yang dilakukan oleh Badan Perencanaan dan Pembangunan Daerah (Bappeda) Kabupaten Bantul, sesuai dengan Surat Perintah Tugas Nomor 094/0981 tertanggal 3 Oktober 2014, diketahui jumlah petambak udang di daerah tersebut adalah 254 dengan total luas lahan yang digunakan sebesar 32,44 ha (Badan Perencanaan dan Pembangunan Daerah Kabupaten Bantul, 2014).

Berkaitan dengan munculnya tambak udang, Pemerintah Daerah Kabupaten Bantul telah menetapkan kebijakan untuk menutup semualokasitambakudang dan merelokasinya ke Desa Wonoroto atau Ngepet, Kecamatan Sanden. Alasan penutupan itu adalah tambak udang mengganggu lingkungan. Posisi tambak udang tersebut telah melanggar tata ruang, melanggar daerah milik jalan lintas selatan, serta melanggar sempadan sungai dan pantai. Pemda Kabupaten Bantul telah menutup 37 tambak udang, tetapi kegiatan relokasi ke daerah tambak udang yang baru belum dilaksanakan karena kebijakan relokasi masih belum jelas. Oleh Pemerintah Daerah Kabupaten Bantul, lokasi yang selama ini digunakan sebagai tambak udang akan direncanakan sebagai daerah pengembangan pariwisata. Meskipun kegiatan tambak udang mereka telah ditutup, kegiatan pembinaan teknis pengembangan tambak udang masih terus dilakukan oleh Dinas Perikanan dan Kelautan Pemerintah Daerah DIY dan Himpunan Nelayan Indonesia sehingga menimbulkan kebingungan pada para petambak udang tersebut.

Menanggapi kebijakan Pemerintah Daerah Kabupaten Bantul mengenai pemanfaatan tanah kesultanan untuk tambak udang, tidak semua petambak menaati kebijakan tersebut. Para petambak udang merasa keberatan karena mereka berpersepsi bahwa mereka memanfaatkan tanah leluhurnya yang selama ini tidak termanfaatkan dengan maksud untuk meningkatkan kesejahteraan mereka. Selain itu, mereka telah mengeluarkan dana yang cukup besar untuk mengembangkan budidaya udang. Para petambak udang juga meragukan keberhasilan rencana relokasi karena selama ini tanah kesultanan di Desa Wonoroto yang merupakan calon lokasi pemindahan telah dimanfaatkan oleh masyarakat setempat. Menurut mereka, hal itu juga akan menciptakan konflik antara mereka dengan masyarakat Desa Wonoroto.

Dinamika persoalan yang terjadi antara petambak udang dan pemerintah daerah dapat menimbulkan perbedaan perilaku yang sangat rentan menimbulkan konflik antaraktor.Para petambak menunjukkan berbagai macam respons terhadap kebijakan tersebut. Respons tersebut 
muncul sebagai bentuk upaya, baik yang dipengaruhi oleh emosi maupun kognitif, untuk menoleransi atau mengurangi stres (Lazarus \& Folkman, 1984; Sarafino, 1990; Keliat, 1999), yang selanjutnya disebut sebagai stategi coping dalam tulisan ini. Strategi coping yang ditunjukkan oleh setiap petambak berbeda tergantung pada pengetahuan mereka tentang pemanfaatan tanah kesultanan. Tulisan ini akan membahas alasan tidak semua petambak udang mematuhi kebijakan pemerintah daerah mengenai penataan pemanfaatan tanah kesultanan.

\section{Metodologi}

Studi ini dilakukan menggunakan metode campuran (mixed method) yang diawali dengan metode kualitatif dan dilanjutkan dengan metode kuantitatif. Sasaran penelitian meliputi masyarakat petambak udang di sekitar Pantai Pandansimo-Depok, Kecamatan Srandakan-Kretek, Kabupaten Bantul, Daerah Istimewa Yogyakarta. Responden atau aktor yang dipilih adalah para petambak udang yang terkena dampak langsung kebijakan penataan pemanfaatan tanah kasultanan untuk tambak udang.

Metode kualitatif diterapkan pada tahap analisis isi. Analisis ini bertujuan untuk memberikan wawasan baru dan meningkatkan pemahaman peneliti tentang strategi coping yang berkembang di masyarakat petambak udang yang terkena dampak kebijakan penataan pemanfaatan tanah kaeultanan untuk tambak udang. Sampel yang dipilih meliputi ketua kelompok, para pemilik tambak, dan masyarakat setempat yang menjadi petani tambak. Data yang berupa catatan lapangan, wawancara, percakapan, foto rekaman, dan catatan pribadi dikumpulkan dalam tahap ini. Namun, wawancara yang dilakukan didasarkan pada asumsi dan kerangka teoretis bahwa masyarakat petambak udang menunjukkan perilaku coping sebagai wujud dari ketidakberdayaan mereka terhadap kebijakan pemerintah. Hasil wawancara kemudian dianalisis dengan pendekatan penafsiran yang naturalistik karena sebelumnya peneliti telah mempelajari kondisi lingkungan alamiahnya (grounded research) sehingga dapat memaknai atau menafsirkan fenomena dari sudut pandang responden. Hal itu menyerupai dengan yang telah didemonstrasikan oleh Creswell (2013). Secara teori, para peneliti yang bekerja pada titik-titik yang berbeda dalam waktu dan mungkin dalam keadaan yang berbeda harus mendapatkan hasil yang sama ketika menerapkan teknik yang sama untuk data yang sama (Creswell, 2013). Oleh karena itu, diharapkan hasil analisis isi yang didapatkan sesuai atau paling tidak mendekati asumsi awal yang dibuat.

Hasil analisis isi menunjukkan adanya perilaku coping masyarakat petambak udang yang terkena dampak kebijakan penataan pemanfaatan tanah kasultanan untuk tambak udang. Berdasarkan hasil tersebut, analisis dilanjutkan untuk mengetahui faktor yang memengaruhi strategi coping yang ditunjukkan. Faktor-faktor tersebut disebut sebagai variabel yang meliputi kognisi, emosi, dan sikap. Selanjutnya analisis dilakukan dengan metode kuantitatif Structural Equation Modeling (SEM). SEM adalah penggabungan antara dua konsep statistik, yaitu konsep analisis faktor yang masuk pada model pengukuran (measurementmodel) dankonsep regresi melalui model struktural (structural model). Model pengukuran menjelaskan hubungan antara variabel dengan indikatorindikatornya, sedangkan model struktural menjelaskan hubungan antarvariabel (Hoyle, 2011). 


\section{Hasil dan Pembahasan}

Lokasi penelitian terletak di Kabupaten Bantul yang berada dalam wilayah administrasi Pemerintah Provinsi Daerah Istimewa Yogyakarta. Secara geografis, Kabupaten Bantul terletak antara 07 44' 04"

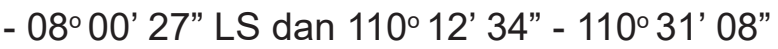
BT. Di sebelah timur kabupaten ini berbatasan dengan Kabupaten Gunungkidul kemudian di sebelah utara berbatasan dengan Kota Yogyakarta dan Kabupaten Sleman, di sebelah barat berbatasan dengan Kabupaten Kulon Progo, serta di sebelah selatan berbatasan dengan Samudera Hindia.

Pada kenyataannya, sebagian besar pemanfaatan lahan untuk tambak udang ditemukan di wilayah pesisir Kabupaten Bantul dengan jumlah luas tambak udang total adalah 32.44 ha (Badan Perencanaan dan Pembangunan Daerah Kabupaten Bantul, 2014). Ketika pengamatan mulai dilakukan di lokasi penelitian, terlihat banyak tambak udang yang berada di tanah kesultanan, bahkan sebagian nelayan, selain mencari ikan di laut, sekarang telah mengembangkan usaha tambak udang di pesisir sepanjang Pantai Pandansimo-Depok, Kabupaten Bantul. Selain di wilayah tersebut, upaya budidaya tambak juga dapat dijumpai di wilayah
Kecamatan Kretek, Srandakan, dan Sanden. Sebagian besar usaha tambak udang tersebut menggunakan tanah kesultanan (Sultanat Grond). Pada 10 Juli 2014 tercatat jumlah kolam tambak di Kecamatan Kretek adalah 22 kolam, di Kecamatan Srandakan 225 kolam, dan di Kecamatan Sanden 42 kolam. Hingga 10 Desember 2014 jumlah ini bertambah menjadi 33 kolam di Kecamatan Kretek dan 229 di Kecamatan Srandakan, sedangkan di Kecamatan Sanden jumlah kolam tetap (Dinas Kelautan dan Perikanan Kabupaten Bantul, 2014; Tabel 1). Ketiga kecamatan tersebut memperlihatkan bahwa jumlah personil yang terlibat dalam kegiatan tambak udang di sepanjang Pantai PandansimoDepok sebanyak 253 orang, masing-masing 76 orang di Kecamatan Kretek, 86 orang di Kecamatan Sanden, dan di Kecamatan Srandakan sejumlah 91 orang dengan tiap personil dapat memiliki lebih dari satu usaha tambak udang. Total usaha tambak udang dari 91 personil tersebut adalah 136 usaha (Tabel 1).

Terkait dengan status tanah yang dipakai untuk usaha tambak udang, seperti yang ditunjukkan dalam Gambar 1, sebagian besar masyarakat di tiga kecamatan tersebut menggunakan Sultanat Grond sebagai lokasi usaha mereka, yaitu sebanyak 25

Tabel 1 Jumlah dan Luas Kolam untuk Kegiatan Tambak Udang di Kecamatan Pesisir Kabupaten Bantul

\begin{tabular}{rlccc}
\hline No & Kecamatan & Usaha & Jumlah kolam & Luas (Ha) \\
\hline 1 & Srandakan & 136 & 229 & 23,42 \\
2 & Sanden & 86 & 42 & 4,51 \\
3 & Kretek & 76 & 33 & 6,07 \\
\hline & Jumlah total & 298 & 304 & 33,99 \\
\hline
\end{tabular}

Sumber: Dinas Kelautan dan Perikanan Kabupaten Bantul, 2014 


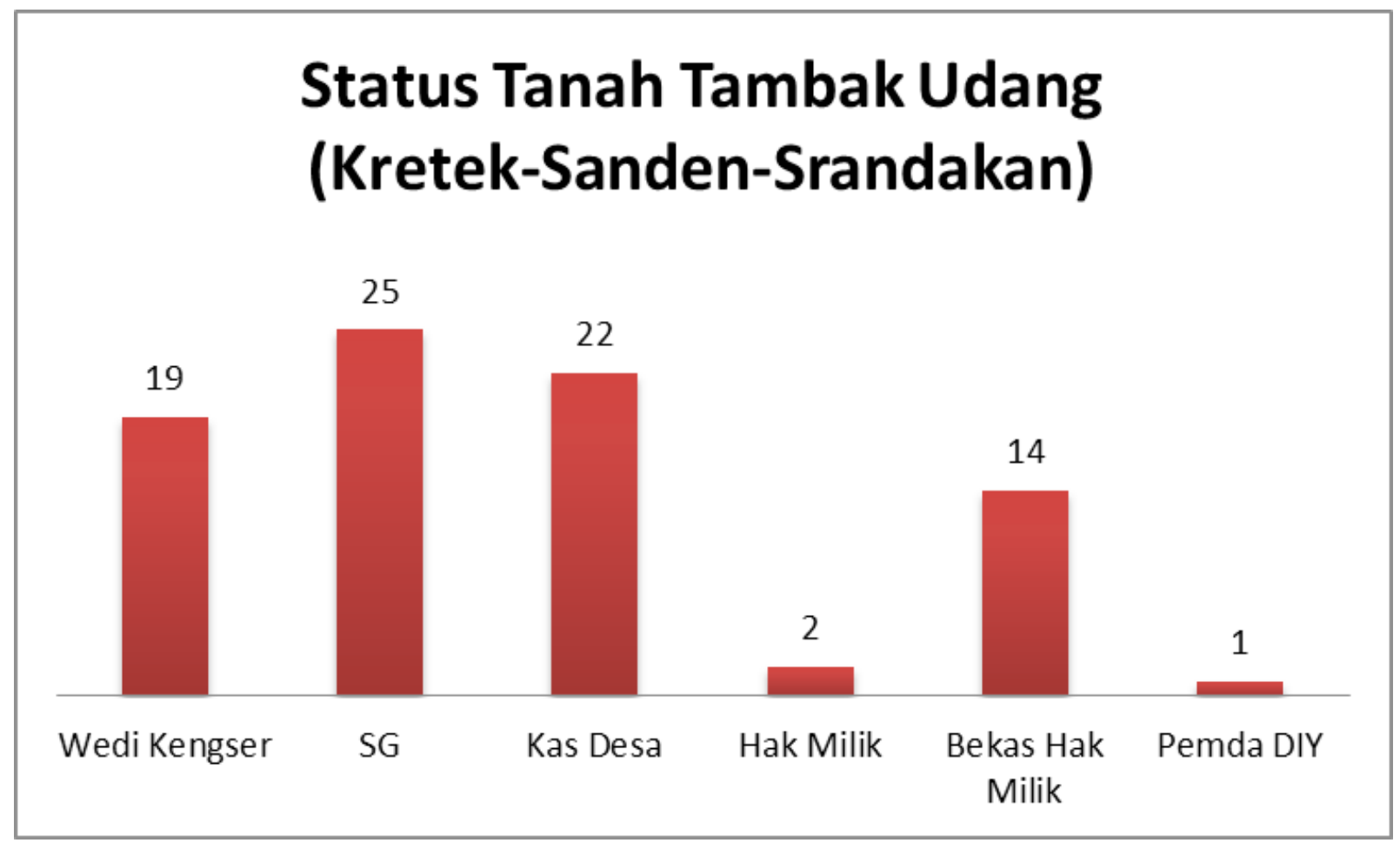

Sumber: Pengolahan Data dari Data Tambak Udang Kecamatan Srandakan, Sanden, dan Kretek oleh Dinas Perikanan dan Kelautan Daerah Istimewa Yogyakarta (2016)

Keterangan: $(\mathrm{SG}=$ Sultanat Grond $)$

Gambar 1 Status Tanah Tambak Udang di Kecamatan Kretek-Sanden-Srandakan

kolam tambak udang. Status tanah lain yang juga mendominasi adalah tanah kas desa sebanyak 22 kolam dan wedi kengser sebanyak 19 kolam Yang mencolok adalah adanya satu kolam usaha tambak udang yang memakai tanah milik Pemda DIY. Sementara itu, kolam usaha tambak udang yang berada pada tanah hak milik hanya sejumlah 2 kolam. Data status tanah yang dimanfaatkan untuk usaha tambak udang di atas mengindikasikan bahwa selama ini para petambak udang di tiga kecamatan tersebut menggunakan lahan yang bukan milik pribadi. Hal inilah yang akhirnya menjadi polemik ketika lahan-lahan tersebut diminta untuk dikosongkan dari aktivitas pertambakan.

Berdasarkan analisis kesesuaian lahan dan konsultasi publik yang telah dilakukan pemerintah daerah, lokasi budidaya tambak udang akan difokuskan pada satu kawasan yang berada di pesisir Kecamatan Sanden. Kawasan yang direncanakan sebagai lokasi tujuan relokasi tambak udang tersebut mempunyai luas sekitar 32,02 ha. Lahanlahan tambak yang berada di luar kawasan tersebut nantinya akan direlokasi ke dalam kawasan tersebut. Rencana pengawasan dan pengelolaan program relokasi akan dilakukan dengan melibatkan pihak swasta.

Hasil wawancara menunjukkan aspekaspek yang mengontrol respons petambak udang terhadap kebijakan penataan tambak udang. Aspek-aspek tersebut kemudian dikategorikan menjadi empat variabel umum, yaitu variabel kognitif, emosi, sikap, dan perilaku. Jenis-jenis aspek yang muncul 
Tabel 2 Variabel Psikologi yang Berkembang dalam Strategi Coping Petambak Udang dalam Menghadapi Kebijakan Penataan Tambak Udang

\begin{tabular}{|c|c|c|}
\hline No. & Variabel & Aspek \\
\hline \multirow{5}{*}{1.} & \multirow{5}{*}{ Kognitif } & Persepsi Negatif \\
\hline & & Perbedaan Pendapat \\
\hline & & Ekspektasi \\
\hline & & Percaya Diri \\
\hline & & Kebingungan \\
\hline \multirow{5}{*}{2} & \multirow{5}{*}{ Emosi } & Kekhawatiran \\
\hline & & Kemarahan \\
\hline & & Takut kehilangan \\
\hline & & Adanya sosok yang dapat dipercaya \\
\hline & & Adanya rasa marah terhadap pemerintah \\
\hline \multirow{10}{*}{3} & \multirow{10}{*}{ Sikap } & $\begin{array}{l}\text { Memiliki kemampuan untuk bertahan dan menyesuaikan diri } \\
\text { (self efficacy) }\end{array}$ \\
\hline & & Adanya penerimaan bersyarat \\
\hline & & Kecewa \\
\hline & & Legawa \\
\hline & & Merasa tidak ada keadilan \\
\hline & & Merendahkan kinerja pemerintah \\
\hline & & Adanya keraguan pada pemerintah \\
\hline & & Kecurigaan \\
\hline & & Munculnya pembelaan diri \\
\hline & & Adanya Ketidakrelaan \\
\hline \multirow{4}{*}{4} & \multirow{4}{*}{ Perilaku strategi coping } & Penerimaan dengan terpaksa \\
\hline & & Mengkritisi keputusan pemerintah \\
\hline & & Adannya sikap menerima \\
\hline & & Adanya sikap evaluasi diri \\
\hline
\end{tabular}

Sumber: Hasil kategorisasi wawancara

dalam hasil wawancara beserta kategorisasi variabelnya dapat dilihat dalam Tabel 2.

Hasil kategorisasi wawancara menunjukkan bahwa aspek variabel kognitif yang berkembang mencakup aspek persepsi negatif; perbedaan pendapat, ekspektasi atau harapan dapat tetap membuka tambak udang, dan kebingungan (poin 1 dalam Tabel 2). Selain kognitif, di lapangan juga berkembang variabel emosi yang terdiri atas aspek kekhawatiran, kemarahan, takut kehilangan, adanya sosok yang dapat dipercaya, dan 
adanya rasa marah terhadap pemerintah (poin 2 dalam Tabel 2). Pada hasil wawancara terhadap informan juga dapat diketahui adanya beberapa macam sikap para petambak udang terhadap kebijakan penataan tambak udang, meliputi memiliki kemampuan untuk bertahan dan menyesuaikan diri, adanya penerimaan bersyarat, kecewa, legawa, merasa tidak ada keadilan, merendahkan kinerja pemerintah, adanya keraguan pada pemerintah, kecurigaan, munculnya pembelaan diri, dan adanya ketidakrelaan (poin 3 dalam Tabel 2).

Dari hasil kategorisasi wawancara yang didapat, terlihat bahwa respons para petambakudang dalam menghadapi kebijakan penataan tambak udang (poin 4 dalam Tabel 2) terdiri atas penerimaan dengan terpaksa, mengkritisi keputusan pemerintah, bersikap menerima, dan mengevaluasi diri. Evaluasi diri yang dimaksud adalah mengakui bahwa diri salah karena telah menggunakan tanah yang bukan hak miliknya, termasuk Sultanat Grond, untuk usaha tambak udang mereka. Pemilihan strategi coping dapat dipandang sebagai faktor yang menentukan kemampuan manusia untuk menyesuaikan diri terhadap situasi yang menekan (stressful life events) (Lazarus \& Folkman, 1984).

Dari keempat perilaku strategi coping yang berkembang, mengkritisi keputusan pemerintah adalah respons yang paling sering muncul yang menunjukkan angka statistik 0,914. Menurut sebagian besar para petambak udang, pemerintah hendaknya mempertimbangkan nilai-nilai kemanusiaan sebelum menentukan kebijakan penutupan tambak udang. Strategi coping yang berkembang selanjutnya secara berturut-turut adalah bersikap menerima $(0,894)$, menerima dengan terpaksa $(0,849)$, dan mengevaluasi diri $(0,561)$. Faktor budaya masyarakat setempat yang cenderung menyimpan atau tidak menunjukkan emosinya secara terbuka boleh jadi melatarbelakangi semua respons yang ditunjukkan.

Guna mengetahui pengaruh dari setiap variabel terhadap variabel lainnya, analisis kuantitatif dengan metode SEM (Structural Equation Model) dilakukan berdasarkan hasil kategorisasi wawancara yang sebelumnya telah ditentukan. Pengujian SEM didasarkan pada lima hipotesis yang telah dibuat sebelumnya dan dapaty dilihat sebagai berikut.

1. Hipotesis $1(\mathrm{H} 1)$ : adanya pengaruh positif kognitif terhadap sikap

2. H2 : adanya pengaruh positif emosi terhadap sikap

3. H3 : adanya pengaruh positif sikap terhadap perilaku

4. H4 : adanya pengaruh positif kognitif terhadap perilaku

5. H5 : adanya pengaruh positif emosi terhadap perilaku.

Hubungan antarhipotesis dapat dilihat pada Gambar 2. Dari kelima hipotesis yang diuji, hanya $\mathrm{H} 1$ dan $\mathrm{H} 4$ yang menunjukkan hasil positif. Dengan kata lain, hanya kedua hipotesis tersebut yang diterima, sedangkan tiga hipotesis lainnya ditolak. Adanya pengaruh positif kognitif terhadap sikap $(\mathrm{H} 1)$ memperlihatkan bahwa peningkatan kognitif akan meningkatkan sikap, sedangkan adanya pengaruh positif kognitif terhadap perilaku (H4) menunjukkan bahwa peningkatan kognitif akan meningkatkan perilaku. Meskipun kognitif terbukti memengaruhi sikap dan perilaku, sikap tidak memengaruhi perilaku seperti yang ditunjukkan oleh hasil pengujian terhadap H3.

Selanjutnya hasil perhitungan dengan metode kuantitatif digunakan untuk menghitung pengaruh langsung dan tidak langsung dari setiap variabel (kognitif, emosi, dan sikap) terhadap perilaku (Tabel 


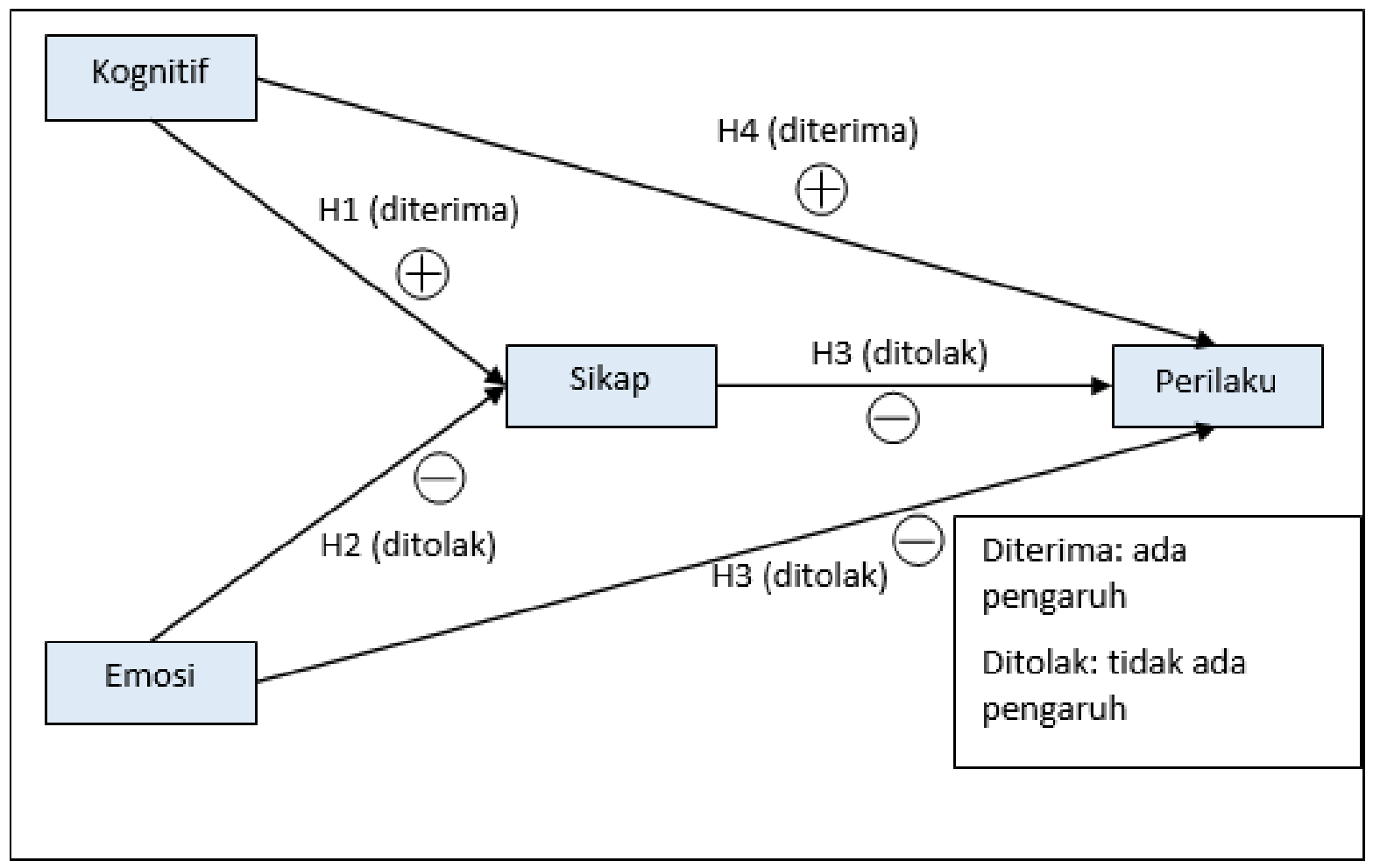

Gambar 2 Interaksi Antarvariabel berdasarkan Hasil Analisis SEM

3). Pengaruh langsung dan tidak langsung akan menghasilkan pengaruh total yang menunjukkan seberapa besar pengaruh dari variabel tersebut dalam mengontrol perilaku strategi coping yang berkembang.

Hasil perhitungan menunjukkan bahwa pengaruh kognitif terhadap perilaku adalah yang paling besar dengan kontribusi total sebesar 0,858 (85,8 persen) (Tabel 3$)$. Pengaruh langsung kognitif terhadap perilaku adalah 1,397 (139,7 persen), sedangkan pengaruh tidak langsungnya terhadap perilaku karena adanya sikap (Gambar 2) adalah 0,520 (52 persen) (Tabel 3). Dari ketiga variabel yang diujikan, variabel kognitif memiliki total pengaruh yang paling besar terhadap perilaku.

Kemudian pengaruh langsung emosi terhadap perilaku adalah 0,291 (29,1 persen), sedangkan pengaruh tidak langsung emosi terhadap perilaku yang dimediasi oleh sikap (Gambar 2) adalah -0,149 (negatif

Tabel 3 Kontribusi Pengaruh Antarvariabel

\begin{tabular}{cccc}
\hline \multirow{2}{*}{ Variabel } & \multicolumn{2}{c}{ Perilaku } & \multirow{2}{*}{ Pengaruh Total } \\
\cline { 2 - 3 } & Pengaruh Langsung & Pengaruh Tidak Langsung & \\
\hline Kognitif & 1.379 & 0.520 & 0.858 \\
\hline Emosi & 0.291 & -0.149 & 0.142 \\
Sikap & -0.668 & - & -0.668 \\
\hline
\end{tabular}

Sumber: Hasil Perhitungan dengan AMOS 
14,9 persen) yang menghasilkan pengaruh total sebesar 0,142 (14,2 persen). Hasil negatif pada pengaruh tidak langsung emosi terhadap perilaku mengindikasikan bahwa arah pengaruhnya berkebalikan. Artinya bahwa peningkatan emosi akan menurunkan perilaku. Berdasarkan hasil perhitungan tidak langsung kognitif dan emosi terhadap perilaku, yang sama-sama melalui variabel sikap, dapat disimpulkan bahwa sikap bukan merupakan variabel mediasi antara kognitif dan emosi terhadap perilaku.

Adanya pengaruh yang besar oleh kognitif terhadap perilaku mengindikasikan bahwa para petambak udang lebih didorong oleh adanya motivasi kognitif di dalam merespons kebijakan penataan tambak udang. Salah satu kriteria individu/masyarakat yang dikontrol dominan oleh aspek kognitif adalah senang berdialog. Oleh karena itu, rekomendasi yang diusulkan untuk menyelesaikan penataan tambak udang didasarkan pada sifat tersebut.

\section{Kesimpulan dan Rekomendasi}

Persepsi setiap informan berbeda, baik mengenai keberadaan tambak udang maupun peraturan yang berkaitan dengan kebijakan penataan pemanfaatan tanah kesultanan untuk tambak udang. Perbedaan ini memberikan perbedaan perilaku stategi coping dalam merespons kebijakan penataan pemanfaatan tanah kesultanan untuk tambak udang. Perilaku strategi coping yang muncul secara berturut-turut berdasarkan statistik yang diperoleh meliputi (1) mengkritisi; (2) menerima dengan legawa; (3) menerima dengan terpaksa; dan (4) menerima dan mengakui bahwa mereka yang salah.

Hasil analisis kuantitatif menunjukkan bahwa perilaku strategi coping yang ditunjukkan oleh petambak udang hanya dipengaruhi oleh variabel kognitif. Jenis variabel kognitif yang paling berpengaruh secara berturut-turut meliputi persepsi negatif, perbedaan pendapat, kebingungan, ekspektasi, dan terakhir indikator percaya diri. Strategi coping para petambak udang tidak dipengaruhi oleh emosi. Hal ini mungkin disebabkan oleh faktor budaya masyarakat setempat yang cenderung menyimpan atau tidak menunjukkan emosinya secara terbuka.

Berdasarkan hasil yang diperoleh, rekomendasi yang dapat diberikan adalah sebagai berikut.

1. Pihak kesultanan sebagai pihak pemilik tanah kesultanan dapat memberikan arahan yang jelas mengenai pemanfaatan tanah tersebut untuk tambak udang.

2. Pemerintah Daerah Kabupaten Bantul, dengan melibatkan pihak kesultanan, mengadakan dialog secara kontinu mengenai pemanfaatan tanah kesultanan untuk tambak udang.

3. Tiap kebijakan publik yang diambil pemerintah perlu berkesinambungan supaya tidak menimbulkan persepsi negatif di tingkat masyarakat.

4. Setiap kebijakan yang telah mempunyai ketetapan hukum harus segera disosialisasikan ke masyarakat, baik melalui kecamatan, desa, maupun tokoh masyarakat.

5. Keberadaan tanah kesultanan lengkap dengan kebijakan pemanfaatan tata ruangnya, misalnya dalam bentuk peta, perlu divisualisasikan.

6. Pemerintah Daerah Kabupaten Bantul dapat memfasilitasi pembuatan aturan pemanfaatan tanah untuk tambak udang dengan memperhatikan lingkungan dan status pemilikan tanah sebagai upaya revisi Peraturan Daerah tentang Rencana Zona Wilayah Pesisir.

7. Pemerintah Daerah Kabupaten Bantul, 
melalui Dinas Pertanahan dan Tata Ruang, dapat membantu menciptakan inovasi kebijakan yang mengatur bagi hasil antara kesultanan dengan rakyat petambak udang.

8. Pemerintah Daerah Kabupaten Bantul dapat menarik retribusi dari para petambak udang kemudian mengembalikan uang yang masuk tersebut sebagai biaya pemulihan lingkungan, misalnya pencegah abrasi laut, pengelolaan limbah air tambak, dan tanaman penghambat angin.

\section{Daftar Pustaka}

Creswell, John. 2013. Penelitian Kualitatif \& Desain Riset: Memilih diantara Lima Pendekatan, terjemahan dari Qualitative Inquary \& Research Design: Choosing Among Five Approaches, Third Edition. First Published 2013, SAGE, ISBN: 9781-4129-9530-6. Edisi Indonesia. Cetakan I, 2015.

Dinas Kelautan dan Perikanan Kabupaten Bantul. 2014. Rencana Zonasi Wilayah Pesisir dan Pulau-Pulau Kecil Kabupaten Bantul Tahun 2014. Dokumen final. Dokumen digital versi tanggal 18/03/2015. Tidak dipublikasikan.

Dinas Perikanan dan Kelautan Daerah Istimewa Yogyakarta. 2016. "Peningkatan Produksi dan Pengembangan Usaha Perikanan Budidaya". Makalah disampaikan pada Rapat Koordinasi Perikanan Budidaya di Provinsi Daerah Istimewa Yogyakarta pada 19 April 2016.

Hoyle, R.H. 2011. Structural Equation Modeling, for Social and Personality Psychology, SAGE Publication Ltd 1 Oliver's Yard 55 City Road London ECIY ISP. ISBN 978-0-85702-403-9.
Keliat, B. A. 1999. "Pengertian perilaku maladaptive". Artikel Kesehatan. Diunduh dari www.FKUNHAS.com dan diakses pada 12 September 2012.

Lazarus, R. S. and Folkman, S. 1984. Stress, Appraisal, and Coping. New York: Springer Publications.

Sarafino, E. 1990. Health Psychology: Biopsychosocial Interactions. New York: John Wiley \& Sons. 